\title{
A Qualitative Study of the Software Adoption of Building Information Modelling Technology in the Hong Kong Construction Industry
}

\author{
Wendy Lee \\ International Graduate School of Business, Division of Business \\ University of South Australia, Australia \\ E-mail: woon.lee@postgrads.unisa.edu.au \\ Anthony Wong \\ School of Computing and Information Science \\ Caritas Institute of Higher Education, Hong Kong \\ E-mail: awong@cihe.edu.hk \\ Canon Tong \\ Business, Government and Law, University of Canberra, Australia \\ E-mail: canon.tong@canberra.edu.au
}

Received: September 17, 2014 Accepted: October 3, 2014

doi:10.5296/ber.v4i2.6319 URL: http://dx.doi.org/10.5296/ber.v4i2.6319

\begin{abstract}
Building Information Modelling (BIM) technology is a powerful technology but is rather new to Hong Kong. The impacts and adoption of BIM in the context of Hong Kong building and construction industry requires an in depth study in order to provide insights for industry to leverage its power. The aim of this research was therefore to identify barriers that affect the adoption of BIM technology in the Hong Kong building and construction industry. A qualitative analysis was conducted on five professionals and experts in Hong Kong building and construction industry to study the effects of the variables of adoption of Building Information Modelling technology. The research results support the research questions and
\end{abstract}


also bring contributions to both academia and the professional environments in the body of knowledge in the BIM field about major factors affecting user adoption of BIM software technology in the Hong Kong building and construction industry.

Keywords: BIM, Software Adoption, Construction, Social Influence, Satisfaction

\section{Introduction}

In recent years, rising energy costs, the building and infrastructure boom, and environmental issues have been hot topics worldwide (Manrai et al., 2001). Furthermore, there are environmental drivers such as global warming that increase the study of green and sustainable building designs. BIM is recognised as using software technology that provides productivity and economic benefits for green and sustainable designs in the global construction industry.

\subsection{Values of BIM Technology}

The value of BIM information lies not only in 3D visualisation, but, more importantly, in design decision-making, producing high-quality construction documents, predicting performance, cost-estimations, construction planning, and even for facilities operation and management at a later stage (Aslani, Griffis and Chiarelli, 2009; Chan, Li and Skitmore, 2012; $\mathrm{Hu}$, Zhang and Deng, 2008; Kim, Kim, Park and Kim, 2011). Recent research in Hong Kong recommends that the industry hasten the transition from 2D CAD to BIM by exploring how to adopt common BIM standards such as specifying modelling method and the level of detail expected of a 3D BIM (Tse, Wong and Wong, 2005). BIM merges electronic versions of paper documents that include $3 \mathrm{D}$ renderings with construction documents, and results in a combination of creating, using, reusing and exchanging coordinated, consistent and computable information (Bernstein \& Pittman, 2004).

BIM is defined as the creation and use of coordinated, consistent, computable information relating to a building project during the design and construction processes (Krygiel \& Nies, 2008). From the software vendor's side, BIM is also interpreted as an integrated process built using information from the entire life cycle of buildings into a 3D model comprising coordinated, reliable information about a project from design through construction and up to operations (Autodesk, 2009; Bentley, 2009; Gehry Technologies, 2009; GraphiSoft, 2009; Nemetschek, 2009; Tse et al., 2005). As the 3D information is parametric in nature, the BIM model is also an integrated database that stores parametric information about the entire building and a complete set of design documents. The project team can work with a model-based framework to ensure that a change from one view will propagate to all other views of the design model.

BIM is an emerging tool in the construction industry not only to the benefit of designing and documenting a project, but also for enhancing communication among all project stakeholders. This tool has begun to change how project designers work with consultants and contractors, and has the ability to assist in guiding the industry in a more sustainable direction. The use of BIM allows professionals to quantify a greener design approach and to resolve issues related to construction waste, energy consumption reduction, $\mathrm{CO}_{2}$ emission control, and to realise the design before construction commences. 
Key benefits of adopting BIM technology include easier coordination of different software and project personnel; improved productivity; reduced cost from reduced communication and design errors; improved communication between designers and builders with 3D/4D visualisation; improved project quality control; improved project outcomes such as fewer field coordination problems; resolving design geometric conflicts at an earlier stage; reviewing clash analysis at an early stage; and ultimately providing an overall positive impact resulting in a winning project (Young, Jones and Bernstein, 2008). Most costs generated throughout the life cycle of a building are incurred during future operations rather than during the design and construction phases.

\subsection{Justification of the Research}

Although academics have carried out a number of BIM-related research studies, in practice, the adoption of BIM by the construction industry is still in its infancy in most countries (Tse et al., 2005). BIM is destined and has the potential to revolutionalise the construction industry at an astonishing pace from the US to Asia. In Hong Kong, the adoption of BIM is slow, and conventional entity-based computer-aided design (CAD) software is still the de-facto drafting tool. The change-management process in different project cultures may be affecting individuals and organisations that are heavily reliant on teamwork for successful project delivery (Rahman \& Kumaraswamy, 2004). In this research, barriers affecting software adoption in BIM technology in the Hong Kong construction industry were analysed by explaining perceived usefulness and usage intentions in relation to process satisfaction and outcome satisfaction when using a BIM system (Fayad, 2006).

\section{Literature Review}

In order to examine the barriers to software adoption, Peansupap \& Walker (2005) commented that the actual implementation of IT is very difficult to control due to the complexity of interaction of people in the workplace and any changed methods that steer away from their usual working patterns. Recent research from Venkatesh, Thong and Xu (2012) stated that there is significant impact of users' habit on their own technology use when they face a diversified and dynamic environment. No matter how much time and cost an IT system may have invested, its adoption may not be as satisfactory as expected if there are barriers or inhibitors to adoptions that affect user intention to use. The Technology Acceptance Model (TAM) framework can be applied to predict user adoption and new technologies usage in both business environment and educational environment (Behrend, Wiebe, London \& Johnson, 2011). Cenfetelli \& Schwarz (2011) noted the importance of focusing on these overlooked barriers or inhibitors so that rejection to use of technology can be prevented. Resistance to change is common among all human beings as we generally acquire habits over a period of time. Factors affecting ICT at the actual implementation stages include complex technical and social issues, however, "people-related factors are crucial" in effective ICT implementation.

The key literature review articles and theories applied are summarised in Table 1. 
Table 1. Key reference model

\begin{tabular}{|c|c|c|c|}
\hline Theory & $\begin{array}{l}\text { Known research topic related to my } \\
\text { research }\end{array}$ & Key Literature & Researchers \\
\hline $\begin{array}{l}\text { Technology } \\
\text { Acceptance Model } \\
\text { (TAM) }\end{array}$ & $\begin{array}{l}\text { Individual's behavioural intention } \\
\text { to use a system is determined by } \\
\text { perceived usefulness and perceived } \\
\text { ease of use. }\end{array}$ & $\begin{array}{l}\text { Perceived usefulness, } \\
\text { perceived ease of use, and } \\
\text { user acceptance of } \\
\text { information technology. MIS } \\
\text { Quarterly } 13 \text { 319-339. }\end{array}$ & Davis, F. D. (1989) \\
\hline $\begin{array}{l}\text { Theoretical } \\
\text { Extension of } \\
\text { Technology } \\
\text { Acceptance Model } \\
\text { (TAM2) }\end{array}$ & $\begin{array}{l}\text { Both social influence processes and } \\
\text { cognitive instrumental processes } \\
\text { significantly influenced user } \\
\text { acceptance. } \\
\text { Subjective norm exerts a } \\
\text { significant direct effect on usage } \\
\text { intentions over and above } \\
\text { perceived usefulness and perceived } \\
\text { ease of use for mandatory (but not } \\
\text { voluntary) systems. }\end{array}$ & $\begin{array}{l}\text { A Theoretical Extension of } \\
\text { the Technology Acceptance } \\
\text { Model: Four Longitudinal } \\
\text { Field Studies. Management } \\
\text { Science 46, pp. 186-204. }\end{array}$ & $\begin{array}{l}\text { Venkatesh, V. \& } \\
\text { Davis, F. (2000) }\end{array}$ \\
\hline $\begin{array}{l}\text { Theoretical } \\
\text { Extension of } \\
\text { Technology } \\
\text { Acceptance Model } \\
\text { (TAM2) }\end{array}$ & $\begin{array}{l}\text { In summary, ease of use of new } \\
\text { technology becomes less } \\
\text { significant with increased } \\
\text { experience for TAM2. However, } \\
\text { gender was not included in the } \\
\text { original TAM. }\end{array}$ & $\begin{array}{l}\text { User acceptance of } \\
\text { information technology: } \\
\text { Toward a unified view. MIS } \\
\text { Quarterly, 27(3), 425-478. }\end{array}$ & $\begin{array}{l}\text { Venkatesh, } \\
\text { Morris, M. G., } \\
\text { Davis , G. B. \& } \\
\text { Davis, F. D. (2003) }\end{array}$ \\
\hline $\begin{array}{l}\text { Extension of } \\
\text { Technology } \\
\text { Acceptance Model } \\
\text { (TAM) }\end{array}$ & $\begin{array}{l}\text { Technology Adoption of } \\
\text { E-Commerce } \\
\text { (My research: Technology } \\
\text { Adoption of BIM) }\end{array}$ & $\begin{array}{l}\text { Extension of the technology } \\
\text { acceptance model in } \\
\text { electronic } \\
\text { Business } \\
\text { Systems. } \\
\text { University. }\end{array}$ & Fayad, R. (2006) \\
\hline
\end{tabular}

\subsection{BIM Technology Trend}

A BIM is a shared knowledge resource for information about a facility, forming a reliable basis for decisions during its life cycle, existing from earliest conception to demolition." From Li et al. (2008 and 2009), BIM simulates the construction project in an accurate virtual environment. According to Wong, Wong and Nadeem (2009), BIM develops and uses a computer model to simulate design, construction and operation of a facility. For project owners, the demand on the 
Leadership in Energy and Environmental Design (LEED) (USGBC, 2009) is growing as it addresses savings in waste avoidance and operation costs after a building has been constructed. Recently, the HK Green Building Council (HKGBC) was established with the support of the Hong Kong Government to drive green building and sustainable design in the city. From local public housing developer such as Hong Kong Housing Authority (2012), BIM is interpreted as "the process of generating three-dimensional, digital representation of building data throughout its life cycle". BIM is innovative for connecting communications among the architecture, engineering and construction industries. By using the data stored in BIM models, different sustainability design and environmental studies could be conducted, such as lighting, ventilation, energy, carbon emission and green design, etc.

To reduce the increasing pressure from climate change, the Hong Kong Government has set up targets for greenhouse gas (GHG) emissions reduction (HKCIC, 2012). Therefore, GHG emissions reduction is a challenge to Hong Kong while the construction industry has a significant role in relation to environmental protection and sustainable construction to build better quality building and contribute in GHG emissions reduction. The Hong Kong Government has proposed 50 - 60\% Carbon Intensity Reduction by 2020, compared to 2005 baseline. In other countries, the UK Government has taken proactive actions to reduce carbon emissions by forcing change on the construction industry through legislation. From recent research in the UK (Hetherington, Laney \& Peake, 2010), the Department of Communities and Local Government conducted a consultation that concluded that there was demand for sustainable practices which go beyond zero carbon buildings (DCLG, 2007). In the future, architects may be required to handle new and demanding knowledge relating to designing sustainable and zero carbon buildings. By making use of timely and understandable data in BIM models, architects would be facilitated in design decision making.

\subsection{Evaluation of the Literature}

As BIM involves the use of technology as well as the changes of working and cultural practices that an industry will experience, the literature review has covered topics including the adoption of information technology (IT); adoption of information and communication technology (ICT); barriers to software adoption; building information modelling (BIM); change management; China; the construction industry; customer satisfaction; globalisation; Hong Kong; learning organisation; perceived usefulness; social influence; software business; technology acceptance model (TAM); and the US.

Architectural, engineering and construction (AEC) companies are the key users that utilise $\mathrm{BIM}$ to reduce communication costs during the design and construction processes. For example, increased coordination between design and detailing can be reduced through the use of shared 3D design models so that any changes can be communicated seamlessly and instantaneously across disciplines (Ekstrom \& Bjornsson, 2004). The use of a shared 3D model facilitates an ease of communications, resulting in the reduction of both uncertainty and communication costs. Besides virtual modelling applications, BIM can also be used effectively as a collaboration platform by key members on project teams such as those in architecture/engineering firms, general contractors or construction managers in the mechanical, 
electrical, plumbing and fire- protection segments. The building's 3D BIM computer-rendered model would contain all of the building's information such as wall materials, structural beams, HVAC equipment, plumbing fixtures, door and window schedules, and finishing details.

\subsection{Research Gap}

Current research on TAM has not addressed the role of other direct determinants of usage intentions and behaviour and, instead, only discusses the major contingency factors moderating the effects of perceived usefulness, perceived ease of use, subjective norm and other constructs on intention (Venkatesh \& David, 2000). Also, previous research has not established how early in a system-development process one is able to begin to measure key user reactions. An example is that direct hands-on training or usage experience may be introduced even before a working prototype is built. In such cases, measurements can be made for post-implementation success of the system concept.

Previous research includes surveys that targeted local Hong Kong architectural firms (Tse et al., 2005) and other countries (Anteroinen, 2005) pointed out some barriers to BIM. Since TAM and the extended model TAM2 have not been applied in the construction industry in BIM technology adoption in Hong Kong, this research was conducted to discover the issues: Subjective Norm, Image, Job Relevance, Result Demonstrability, Process Satisfaction, Outcome Satisfaction, Perceived Ease of Use and Perceived Intention to Use.

Research gap of current research have resulted in identifying five research problems defined as follows:

Research problem 1: What are the barriers to the adoption of BIM in Hong Kong's construction industry?

Research problem 2: How much do these barriers affect BIM adoption?

Research problem 3: What are the major factors facilitating the adoption of BIM?

Research problem 4: Will an individual user have better process satisfaction and outcome satisfaction if the company supports the use of BIM on a voluntary basis?

Research problem 5: Can process satisfaction and outcome satisfaction facilitate intention to use BIM for an individual?

\section{Methodology}

Interviews were conducted among five industrial experts in Hong Kong to validate research questions and to provide insights on the barriers of BIM adoption for Hong Kong building and construction industries. Details of the five industrial experts interviewed were shown below in Table 2.

Table 2. Details of five industrial experts interviewed

\begin{tabular}{|l|l|l|l|l|}
\hline $\begin{array}{c}\text { Respondent } \\
\text { Code }\end{array}$ & \multicolumn{1}{|c|}{ Role } & Date interviewed & Place of interview & \multicolumn{1}{|c|}{$\begin{array}{c}\text { Duration of } \\
\text { interview }\end{array}$} \\
\hline A & $\begin{array}{l}\text { BIM Consultant of a BIM } \\
\text { consultant firm }\end{array}$ & $\begin{array}{l}19 \text { April 2012 } \\
\text { (Thur) }\end{array}$ & $\begin{array}{l}\text { Hotel Icon, Tsimshatsui, } \\
\text { Hong Kong }\end{array}$ & $1 \frac{1}{2}$ hours \\
\hline
\end{tabular}




\begin{tabular}{|l|l|l|l|l|}
\hline B & $\begin{array}{l}\text { Architect/BIM Manager of a } \\
\text { developer }\end{array}$ & $\begin{array}{l}22 \text { April 2012 } \\
\text { (Sunday) }\end{array}$ & $\begin{array}{l}\text { Olympian } \\
\text { Taikoktsui, Hong Kong }\end{array}$ & $11 / 2$ hours \\
\hline C & $\begin{array}{l}\text { BIM Project Manager of a } \\
\text { BIM consultant firm }\end{array}$ & $\begin{array}{l}23 \text { April 2012 } \\
\text { (Monday) }\end{array}$ & $\begin{array}{l}\text { APM, Kwun Tong, } \\
\text { Hong Kong }\end{array}$ & $1 \frac{1}{2}$ hours \\
\hline D & $\begin{array}{l}\text { BIM Director of an } \\
\text { engineering consultant firm }\end{array}$ & $\begin{array}{l}23 \text { April 2012 } \\
\text { (Monday) }\end{array}$ & $\begin{array}{l}\text { APM, Kwun Tong, } \\
\text { Hong Kong }\end{array}$ & $1 \frac{1}{2}$ hours \\
\hline E & $\begin{array}{l}\text { Architect of a BIM } \\
\text { consultant firm }\end{array}$ & $\begin{array}{l}20 \text { April 2012 } \\
\text { (Friday) }\end{array}$ & $\begin{array}{l}\text { APM, Kwun Tong, } \\
\text { Hong Kong }\end{array}$ & $1 \frac{1}{2}$ hours \\
\hline
\end{tabular}

The purpose of the qualitative approach is to discover the underlying facts, reasons and incidents related the research problems and questions. The interview questions were shown on Table 3.

Table 3. Summary of Interview Questions

\begin{tabular}{|c|l|}
\hline$\#$ & Interview question \\
\hline 1 & $\begin{array}{l}\text { How does Subjective Norm relate to intention to use the BIM system? } \\
\text { Please give examples. }\end{array}$ \\
\hline 2 & $\begin{array}{l}\text { How does Subjective Norm relate to perceived usefulness of the BIM system? } \\
\text { Please give examples. }\end{array}$ \\
\hline 3 & $\begin{array}{l}\text { How does Image of using the BIM system relate to perceived usefulness of the BIM system? } \\
\text { Please give examples. }\end{array}$ \\
\hline 4 & $\begin{array}{l}\text { How does Job Relevance relate to perceived usefulness of the BIM system? } \\
\text { Please give examples. }\end{array}$ \\
\hline 5 & $\begin{array}{l}\text { How does Result Demonstrability of using the BIM system relate to perceived usefulness of the BIM } \\
\text { system? Please give examples. }\end{array}$ \\
\hline 6 & $\begin{array}{l}\text { How does Process satisfaction relate to intention to use the BIM system? } \\
\text { Please give examples. }\end{array}$ \\
\hline 7 & $\begin{array}{l}\text { How does outcome satisfaction relate to intention to use the BIM system? } \\
\text { Please give examples. }\end{array}$ \\
\hline 8 & $\begin{array}{l}\text { How does perceived ease of use relate to perceived usefulness of the BIM system? } \\
\text { Please give examples. }\end{array}$ \\
\hline 9 & $\begin{array}{l}\text { How does perceived ease of use relate to intention to use the BIM system? } \\
\text { Please give examples. }\end{array}$ \\
\hline
\end{tabular}

\section{Results and Findings}

Based on this design, interview contents from 5 respondents were analysed and the summary and explanation of the interview results with respect to the research questions were discussed below.

\subsection{Subjective Norm and Intention to Use the BIM System}

The views of the experts support that subjective norm affects the intention to use BIM. Respondent $\mathrm{A}$ and $\mathrm{B}$ mentioned that the decision to use BIM is made by company top management, who is influenced by a higher level subjective norm. In the case of Hong Kong building and construction industry, this higher level subjective norm is the Hong Kong Housing Authority who specifies vendors to use BIM. The intention by top management to use $\mathrm{BIM}$ is viewed by other as a way to be more competitive. Company top management is viewed as a subjective norm to the lower level workers and downstream contractors. Respondent $\mathrm{C}$ provided an insight that when top management, viewed as a subjective norm to the lower level workers, the decision to use BIM instill an urgency to use BIM. The views of industrial experts and the cases support the claim of Fishbein \& Ajzen (1975) that subjective norm is a direct 
determining factor of behavioral intention in Theory of Reasoned Action, which means that when someone who is important to the user thinks that it is important for the user to perform the task, this will affect user's intention to perform the task.

\subsection{Subjective Norm and Perceived Usefulness of the BIM System}

The views of the experts support that subjective norm affects the perceived usefulness of the BIM system. In cases like clash analysis and project resource allocation, workers think that the higher level management as a subjective norm, as evaluated BIM as a better tool to solve the problems. This affects their perceived usefulness of the BIM system. Respondent B pointed out that a subject norm in Hong Kong made contractors believed that using BIM could better handle the safety issues in public housing construction. Respondent D pointed out that when a company boss, who is in the capacity to evaluate new technology to improve productivity, may become a subjective norm to the company staff. This type of subject norm will be able to explain the benefits of BIM more accurately. This supports the claim of Salancik \& Pfeffer (1978) that subjective norm has an indirect effect on intention through perceived usefulness.

\subsection{Image of Using the BIM System and Perceived Usefulness of the BIM System}

The views of the experts support that image of using the BIM system affects perceived usefulness of the BIM system. According to the respondents, image of using BIM system is associated to being innovative (respondent A), efficient management, safety improvement (respondent C) and use of green technology. As a result of these perceptions, company's marketing promotions are happy to claim that the company knows or uses BIM. Respondent A pointed out that the positive feedback of using BIM has actually improved the company image. The views of experts support the findings of Venkatesh \& Davis (2000), and Chan \& Lu (2004) that image of using an innovation affects a person's perceived usefulness.

\subsection{Job Relevance and Perceived Usefulness of the BIM System}

The views of the experts support that job relevance affects perceived usefulness of the BIM system. Incidence was cited by respondent $C$ when quantity surveyors who were using BIM saw that other contractors were also using BIM, they tended to think that BIM must be very useful in order for other contractors to use it. When BIM delivers results, workers feel that is it relevant and useful. The views of experts support the findings of Venkatesh \& Davis (2000) that job relevance has a direct and positive effect on image of using the system.

\subsection{Result Demonstrability of Using the BIM System and Perceived Usefulness of the BIM System}

The views of the experts support that result demonstrability affects perceived usefulness of the BIM system. According to the respondent $\mathrm{C}$ and $\mathrm{D}$, result demonstrability comes in the form of better return on investment (ROI), more efficient design process, reduction of costly construction waste, and better solution on safety issues. Respondent A pointed out that when BIM shows the positive results in a project, people's perceived usefulness was increased. They also thought that BIM would be able to deliver similar results for the next project. The views of expert support the claim by Venkatesh \& Davis (2000) that result demonstrability in TAM2 has 
direct influence on perceived usefulness of the system.

\subsection{Process Satisfaction and Intention to Use the BIM System}

The views of some experts support that process satisfaction affects intention to use the BIM system. For workers that enjoy the process of using BIM, they will have a greater intention to use BIM for the next project. Respondents mentioned two types of process satisfaction. One is the fact that BIM has the features they want and were able to solve their problems. The process of using BIM becomes meaningful and objective driven. The other being the workers just enjoyed the process of using new technology. For example, some Architects like to adopt BIM during design stage and enjoy the process of innovative design using new technology (respondent C). To senior managers who do not need to use the BIM but only use the BIM output for discussion and analysis, they do not have feel about the process satisfaction. These findings support the claim of Venkatesh \& Davis (2000) and Fayad (2006), that when users are satisfied with the process and outcome of using the system, it increases the intention of the users to use the system again.

\subsection{Outcome Satisfaction and Intention to Use the BIM System}

The views of experts support that outcome satisfaction affects intention to use the BIM system. According to respondent A, a successful precedent in using BIM may lead to a continuous adoption of BIM in a second project, and vice versa. Outcome satisfaction came in the form of number of task users were able to complete. The number of tasks BIM can help to accomplish has made the work process more efficient (respondent B). Outcome satisfaction also came in the form of award winning (respondent $\mathrm{C}$ ). One example is a project manager who managed a project with BIM system and received an innovative design award of the year by using BIM. These positive outcome satisfactions have resulted in greater intention to use BIM for future projects. These findings support the claim of Venkatesh \& Davis (2000) and Fayad (2006), that when users are satisfied with the process and outcome of using the system, it increases the intention of the users to use the system again.

\subsection{Perceived Ease and Perceived Usefulness of the BIM System}

The views of most experts support that perceived ease of use affects perceived usefulness of the BIM system. When a good demonstration and training were given to users, it brought about positive impact on perceived usefulness (respondent E). Similar view is shared by respondent $\mathrm{C}$, that a successful demonstration is important to give a good first impression that affect the perception of usefulness of the BIM system. Perceived usefulness of the system is very clear when showing the 3D models (e.g. clash analyses) output of BIM. Viewers of these outputs were able to appreciate the difficulties of using 2D design for similar analysis (respondent $\mathrm{A}$ ). BIM seems to perform the same analysis in a less painful way. The views of the experts support the claim by researchers that perceived ease of use is positively correlated with perceived usefulness (Venkatesh \& Davis, 2000; Davis, Bagozzi and Warshaw 1989; Halawi \& McCarthy, 2008; and Yi, Jackson, Park and Probst, 2006).

\subsection{Perceived Ease of Use and Intention to Use the BIM System}


The views of some experts support that perceived ease of use affects intention to use the BIM system. Two ways to create perceived ease of use are good demonstration and training on what BIM can do (respondents $\mathrm{C}$ and $\mathrm{E}$ ). Similar view is shared by respondent $\mathrm{C}$, that a successful demonstration is important to give a good first impression that affect the intention to use the BIM system. The views of experts confirm the findings of the past researchers that perceived ease of use is positively correlated with intention to use the system (Halawi \& McCarthy, 2008; Chau \& Hu, 2002; Venkatesh \& Morris, 2000; Szajna, 1996; Taylor \& Todd, 1995).

\section{Discussion}

Interviews with five industrial experts provided valuable insights on adoption of BIM in Hong Kong industry. The following sections summarized the significance of BIM to Hong Kong industry in practice.

\subsection{Significance of Subjective Norm}

The qualitative results support that subjective norm affects the intention to use BIM. The effect of subjective norm in terms of "industry leaders outside a company" is significant as well as the direct report manager of a person to both intention to use the BIM system and its perceived usefulness. The degree of influence is higher for people at the working level than the management level. The subjective norm will be more related to intention to use the BIM system for people at the working level as usually decisions of using a new technology are made by the management level as commented by respondent A. However, professional judgment may also affect the intention to use the BIM system. According to respondent D, if a job nature or responsibilities require the use of BIM or can get benefit from using it, the effect of subjective norm may not be that significant. A simple example is like a young kid choosing to play badminton or basketball at school to fulfil extra-curricular activities marks. As long as the act can be credited, the kid may make the decision even though his/her parents may have different suggestions.

Subjective norm has major impacts on large number of contractors when viewed as industry norm. According to respondent B, when Hong Kong Public Housing Projects specified BIM technology as a requirement, it affects many downstream contractors to see BIM as a tool to stay competitiveness. Public Housing Projects specifying using BIM seemed to endorse BIM's creditability as a form of "industry norm". Contractors who were not using BIM began to show interest and seriousness to adopt BIM as part of the work process. Contractors tended to view this "industry norm" satisfy the safety requirements of the project. As such, it affected their perception of BIM because many contractors were already using BIM. They thought that BIM is useful with much detailed investigation.

The immediate implication of this result is that company leaders should be aware that important subjective norms like Hong Kong Public Housing Authority advocates use of BIM. They should take immediate actions to explore, try or learn the use of BIM as part of company vision and strategies before they become outdated in their technologies and productivity. Company leaders could also learn from other subjective norms specific ways BIM support the strategic development of a company. The broader implication to this is the setup of BIM leader 
forum where company leaders could meet and share strategies of using BIM. This sharing could mature the strategic use of BIM so as to develop a mature adoption framework for Hong Kong companies.

\subsection{Significance of Image, Job Relevance and Result Demonstrability}

The influence of image, job relevance and result demonstrability also play an important role to perceived usefulness of the BIM system. In Hong Kong, corporate social responsibilities are emphasized, and design with innovation and less wastage to the environment gives a positive branding image for companies in the building and construction industry. According to Respondent C, a company may employ external team to help conducting BIM technology if no capable internal team is available. For companies that make use of green ICT technologies for design and construction work, will be able to gain "green branding image" for marketing purpose. For example, if a project is deployed by BIM design approach for making effective design decisions at a project's earlier stages of planning and design, the actions and results that prevent and save construction waste will establish a thought leader image among the industry stakeholders. Corporate image, when expected by clients to get the job done, caused companies to seek active adoption of BIM in various forms. From all five experts, some companies may not have sufficient staff to implement new BIM technology. Some companies will employ external BIM consultants or recruit new BIM-enabled staff to work on new project and maintain the BIM capabilities for better image and increased competitiveness.

According to experts, BIM indeed help professionals to deliver better results. Job Relevance is highly significant to professionals such as quantity surveyors. According to respondent B, if a new system can fulfill the job requirements with better productivity and efficiency, this will impact the perception of usefulness of the BIM system. For example, a developer may look at how other developers use BIM system in handling hotel project if they also need to manage hotel project. According to current BIM adoption in Hong Kong, job relevance is getting more and more significant after increasing number of Government Departments started to conduct trial projects and full implementation projects. This has helped to create new momentum in the building and construction industry that BIM design approach may have high chance to relate to daily work.

According to industry experts, results of using BIM were positive to the projects of the companies. They came in the form of reusability of the system for future projects, actual workable showcases, cost-saving clash analysis, reduction of construction waste, well-coordinated work process, company awards, and good references. These actual results were generated by companies using BIM for a period of time for their projects. Management used these results to calculate ROI in order to justify why the company should adopt BIM at a deeper level.

\subsection{Significance of Process Satisfaction and Outcome Satisfaction}

Although the process satisfaction of using BIM varied according to users' personalities and attitudes, BIM has created a different degree of process satisfaction. Some fast-learners architects adopted BIM during design stage and enjoyed the process of innovative design using 
new technology. This has helped them to use the BIM system in future projects. This early adoption of BIM has put them at a higher ground as compared to others who had not adopted BIM. Refer to comments from respondent $\mathrm{E}$, performance is quantitative while satisfaction is qualitative. Past good experience or painful experience in implementing BIM design approach will influence the intention to use the BIM system in the future, no matter the usage has high values or not. In practical world, staff training before starting a project is important to overcome the learning curve and achieve higher chance of process satisfaction.

The positive outcome satisfaction of using BIM has led to continuous adoption of BIM. Due to the success of the first project that used BIM, companies had continued to use BIM for future projects. Some companies found that BIM was able to help them to solve urgent tasks, which resulted in winning external awards and internal recognition. BIM helped companies to set target tasks and see through the process and evaluate the outcomes. The actual outcomes can be evaluated with respect to the planned objectives. These evaluation results are significance to the ROI of a project. For Hong Kong situation, Government usually will be more likely to spend more budgets on infrastructure projects during economic downturn to boost up the local market. As more building projects funded by the Government request to use BIM since design phase to construction phase for better quality buildings, more obvious outcome in winning more projects by BIM skills have contributed to significance of this factor to BIM adoption. However, outcome satisfaction may not be as important as job relevance and process satisfaction. According to Respondent E, a staff may not want to use the BIM system if overtime work is required frequently. This is common in Hong Kong as many people use after office hours for continuous professional development study, or take a rest after stressful work. In some extreme cases, one may choose to earn less income, but possess more free time after office hours for pleasure.

\section{Limitations and Recommendations for Further Studies}

This research used qualitative study and interviewed five professionals. It is recommended to conduct quantitative study as well by providing more empirical results together with the qualitative findings in order to enhance the value of this research. Besides interview, focus groups could be used to gather more experts' opinions. This research contains data obtained from BIM practitioners in Hong Kong from a number of organisations. One direction that future researchers could take is to study the data of a new project starting from the design phase and seeing it through to the construction phase and even on to the facilities-management phase. The current research was conducted on voluntary settings as this is suitable to the types of theories employed in user acceptance research on technology. Future research could be conducted in purely compulsory settings and thereby observe the user acceptance through skills acquired against time. However, Hong Kong has not yet reached such an advanced stage, and most projects that use BIM now would only do so during certain parts of the project. In the research, some respondents participated either at the design stage or at the construction stage of a project, but not over the whole project life cycle. Therefore, it would be prudent to recommend that future researchers conduct their studies on a complete project that begins at the design stage, leads on to the construction stage and eventually ends at the facilities-management stage. Such processes could potentially take a few years. 


\section{Conclusion}

This research has achieved all the pre-defined objectives and has provided findings to explain the five research problems. This research contributes to both, the academic and the practical fields, specifically on individual software usage adoption barriers for the Hong Kong building and construction industry. In academia, the research provides a complete understanding of user adoption behaviour for TAM2: the significant effects of subjective norm on usage intentions over and above perceived usefulness and how the perceived ease of use can also be applied to voluntary systems in different industries.

The results of qualitative study of this research contribute to improving the understanding of user adoption behaviour of BIM technology in the Hong Kong building and construction industry. Interviews with industrial experts show that BIM adoption was significant in the aspects of subjective norm, image, job relevance, result demonstrability, process satisfaction and outcome satisfaction. The positive results of BIM adoption provided continuous usage of BIM among Hong Kong companies. Cost of construction money as well as cost of damage to the environment is important factor. When labour shortage issue in building and construction industry is getting worse in Hong Kong, BIM is a significant tool to reduce the construction cost while implementing better quality building.

\section{References}

Anteroinen, S. J. (2005). 3D Design Extends from Screen to Site and Beyond. Nordicum, 6, 54-55.

Aslani, P., Griffis, F. H., \& Chiarelli, L. (2009). Building Information Model: The Role and Need of the Constructors. Construction Research Congress, ASCE, http://www.ascelibrary.org

Autodesk ed. (2009). Autodesk Homepage, accessed 1 March 2009, http://www.autodesk.com/bim

Behrend, T. S., Wiebe, E. N., London, J., \& Johnson, E. (2011). Cloud computing adoption and usage in community colleges. Behaviour \& Information Technology, 30(2), 231-240. http://doi: 10.1080/0144929X.2010.489118

Bentley ed. (2009). Bentley Homepage, accessed 1 December 2009. http://www.bentley.com

Bernstein, P. G., \& Pittman, J. H. (2004). Barriers to the Adoption of Building Information Modeling in the Building Industry. Autodesk Building Solutions Whitepaper, Autodesk Inc., CA.

Chun, C. K., Li, H., \& Skitmore, M. (2012). The use of virtual prototyping for hazard identification in the early design stage. Construction Innovation: Information, Process, Management, 12(1), 29-42. http://dx.doi.org/10.1108/14714171211197481

Chan, S. C., \& Lu, M. T., (2004). Understanding Internet Banking Adoption and Use Behavior: A Hong Kong Perspective. Journal of Global Information Management, 12(3), 21-43. http://doi: 10.4018/jgim.2004070102 
Cenfetelli, R., \& Schwarz, A. (2011). Identifying and Testing the Inhibitors of Technology Usage Intentions, Information Systems Research, 22(4), 808-823. http://doi:10.1287/isre.1100.0295

Davis, F. D. (1989). Perceived usefulness, perceived ease of use, and user acceptance of information technology. MIS Quarterly, 13(3), 319-339. http://doi:10.2307/249008.

Davis, F. D., Bagozzi, R. P., \& Warshaw, P. R. (1989). User Acceptance of Computer Technology: A Comparison of Two Theoretical Models. Management Science, 35(8), 982-1002. http://dx.doi.org/10.1287/mnsc.35.8.982.

Ekstrom, M., \& Bjornsson, H. (2004). Information Technology and Purchasing Strategy: Two Necessary Enablers of More Efficient Construction Processes. Center for Integrated facility Engineering (CIFE) Technical Report \#160.

Fayad, R. (2006). Extension of the technology acceptance model in electronic commerce Business Information Systems. Utah State University.

Gehry Technologies ed. (2009). Gehry Technologies. Accessed 1 December 2009, http://www.gehrytechnologies.com

GraphiSoft ed. (2009). GraphiSoft Homepage. Accessed 1 December 2009, http://www.graphisoft.com

Hetherington, R., Laney, R. C., \& Peake, S. (2010). Software engineering challenges: Achieving zero carbon buildings by 2019. In: ACM-BCS Visions of Computer Science 2010, 13-16 April 2010, Edinburgh University.

Hong Kong Housing Authority (HKHA) ed. (2012). Building Information Modelling, accessed 17

http://www.housingauthority.gov.hk/en/business-partnerships/resources/building-informationmodelling/index.html

Hong Kong Green Building Council ed. (2011). HKGBC Homepage, accessed 1 June 2011, http://www.usgbc.org.hk

Hu, Z., Zhang, J., \& Deng, Z. (2008). Construction process simulation and safety analysis based on building information model and 4D technology. Tsinghua Science \& Technology, 13(S1), 26-272. DOI: 10.1016/S1007-0214(08)70160-3.

Kim, C., Kim, H., Park, T., \& Kim, M. K. (2011). Applicability of 4D CAD in Civil Engineering Construction: Case Study of a Cable-Stayed Bridge Project. Journal of Computing in Civil Engineering, 25(1), 98-107. http://dx.doi.org/10.1061.

Krygiel, E., \& Nies, B. (2008). Green BIM: Successful Sustainable Design with Building Information Modeling, Wiley Publishing, Inc.

Nemetschek ed. (2009). Nemetschek All Plan, accessed 22 November 2007, http://www.nemetschek.com 
Peansupap, V., \& Walker, D. H. T. (2005). Factors Enabling Information and Communication Technology Diffusion and Actual Implementation in Construction Organisations. ITcon, 10, 193-218.

Rahman, M. M., \& Kumaraswamy, M. M. (2004). Contracting Relationship Trends and Transitions. Journal of Management in Engineering, 20(4), 147-161. http://dx.doi.org/10.1061/(ASCE)0742-597X(2004)20:4(147)

Taylor, S., \& Todd, P. A. (1995). Assessing IT Usage: The Role of Prior Experience. MIS Quarterly, 19(4), 1995, 561-570. http://dx.doi.org/10.2307/249633

Tse, K. T. C., Wong, A. K. D., \& Wong, F. K. W. (2005). The Utilisation of Building Information Models in $\mathrm{nD}$ Modelling: A Study of Data Interfacing and Adoption Barriers, ITcon, 10, Special Issue From 3D to nD modelling, 85-110.

Venkatesh, V., Thong, James Y. L., \& Xu, X. (2012). Consumer Acceptance and Use of Information Technology: Extending the Unified Theory of Acceptance and Use of Technology. MIS Quarterly, 36(1), 157-178, 2012. Available at SSRN: http://ssrn.com/abstract=2002388

Venkatesh, V., \& Davis, F. D. (2000). A Theoretical Extension of the Technology Acceptance Model: Four Longitudinal Field Studies. Management Science, 46(2), 186-204. http://dx.doi.org/10.1287/mnsc.46.2.186.11926

Venkatesh, V., Morris, M. G., Davis, G. B., \& Davis, F. D. (2003). User acceptance of information technology: Toward a unified view. MIS Quarterly, 27(3), 425-478.

Wong, A. K. D., Wong, F. K. W., \& Nadeem, A. (2009). Attributes of Building Information Modelling and its Development in Hong Kong. The Hong Kong Institute of Engineers Transactions, 16(2), 38-45. http://dx.doi.org/10.1080/1023697X.2009.10668156

Yi, M. Y., Jackson, J. D., Park, J. S., \& Probst, J. C. (2006). Understanding information technology acceptance by individual professionals: Toward an integrative view. Information \& Management, 43(3), 350-363. http://dx.doi.org/10.1016/j.im.2005.08.006

Young, N. W., Jones, S., \& Bernstein, H. M. (2008). Building information modeling (BIM): Transforming the design and construction industry to achieve greater industry productivity. McGraw-Hill Construction.

\section{Copyright Disclaimer}

Copyright for this article is retained by the author(s), with first publication rights granted to the journal.

This is an open-access article distributed under the terms and conditions of the Creative Commons Attribution license (http://creativecommons.org/licenses/by/3.0/). 